\title{
The Impact of Integration of Instructional Systems Technology into Research and Educational Technology
}

\author{
Baharak Makki ${ }^{1}$, Bahador Makki ${ }^{2}$ \\ ${ }^{1}$ Department of Engineering, Faculty of Technology and Science, University of Agder, Grimstad, Norway \\ ${ }^{2}$ Faculty of Law, University of Bremen, Bremen, Germany \\ Email: Baharakm@uia.no,b.makki@uni-bremen.de
}

Received January $23^{\text {rd }}, 2012$; revised February $28^{\text {th }}$, 2012; accepted March $5^{\text {th }}, 2012$

\begin{abstract}
This paper aims at presenting a review about instructional system technology integration in educational literature. Transitional periods of educational technology are discussed and principles of integration of instructional technology in educational technology are reviewed.
\end{abstract}

Keywords: Instructional Technology; Educational Technology; Technology Integration

\section{Introduction}

Papers concerning instructional technology discuss a lot of matters besides educational technology (ET). What is "instructional technology" (IT)? Is it merely a synonym for computers, or does its meaning transcend hardware and software to include both physical and intellectual facets in its domain? What problems define the field of instructional design and technology (IDT)? These questions are in many instructional technologists' minds in response to major shifts in delivery media, delivery infrastructure, design and development software, learning theory, instructional theory, and design theory. How broad is the scope of questions? How well-expressed are the field's problems, and how well directed and founded is the research?

\section{Instructional Technology}

There are different concepts of this filed in our minds. The concept of ET (or IT?) is a general evolution to enter a course of subjective perceptions to the National Education system. To become clearer, we will study the concept of ET during the steps that the concept has been examined. Of course, this process is related to the years after 1900. In the years before 1900, sometimes teachers have brought either some real object to classroom or students were taken to visit museums. About ways to work before 1900, Sattler (1968) and Amir Ebrahimi (1987) provide much information about pioneers in the field of ET.

ET has passed from four stages during the transitional period and has now entered the fifth stage. Most countries have experienced this process and each person can bring a sample of this process in their country. ET consists of five steps as follows:

1) The first step-the tools and equipments

2) The second step-training materials

3) The third step-system courses

4) The fourth step-educational systems

5) The fifth step-social systems

First, we explain each of these steps, and then a survey of ET is provided.

The first step - the tools and equipments: In the years 1900 instrument manufacturers began to make different projectors.
At first they did not aim at projectors used in schools, but these tools were slowly seeping in schools. These tools were able to display images on the screen, and sometimes, files were produced simultaneous with the sound. Since then, schools continued to be equipped with various tools such as projectors, tape recorders or phonographs and found out that they cannot respond to their needs and problems without these educational tools.

The second step - training materials: Industries hired other people to work and start production of materials needed at schools. After this, educational films were made for schools and books and maps were published for special children. Some research done in this period of evolution of educational technology was about the effect of color, size and image files on education. But it was soon realized that most of the time, significant differences between traditional instructions and education through the expensive material does not exist, but other elements such as teacher and student involvement in teaching and learning.

The third step—systems curriculum: In this period, all equipment and materials were used to the service of a larger system which was an educational system. And experts looked at learning of the whole school as a system. That is the reason why professionals in this period designed educational systems. In this phase, course of regular instruction (training) or technological education (teaching) was designed. Retraining teachers, production of new materials, adding educational spaces, enhancing library facilities and laboratories all those cases were related to managers' attitude education systematic affairs. Experts admit that the system had a fundamental change in the course of raising the quality of teaching and learning, but also a third phase of learning was not enough to know the real needs of learner.

The fourth step - the educational system: At this stage, all written, auditory and visual educational materials are prepared based on the society needs. In other words, both individuality (individual's needs) and the community needs are paid attention. Facilities are usually provided on-site for learning, but people are responsible for their own learning. Regular training is not only like formal school education, but also is done at the com- 
munity level.

The fifth stage-the social system: Fifth stage of the concept of educational technology is more like a governing philosophy over a total education in a country to achieve development objectives. At this stage of technology, special training is not for particular individuals or organizations; however it covers the domain of individual or organizational activity, who are working for development in the country.

\section{Education Technology}

Let us start with trying to understand the concept of technology. Although Webster's New Collegiate Dictionary takes a sociological perspective in its definition of technology as “... the totality of the means employed to provide objects necessary for human sustenance and comfort" and "a technical method of achieving a practical purpose," the prevailing public definition based on current usage is "technology equals machinery." This limited focus on machinery at the expense of process ignores the true sense of technology as "the systematic application of scientific and other organized knowledge to practical tasks" (Galbraith, 1967) and thus as a problem-solving process using human and other resources to seek solutions to human problems.

Within this broader sociological framework of technology, we find the terms "educational technology" and "instructional technology". Often used interchangeably, both share a common interest in the processes of human learning and teaching, with some variations in definitions and levels of complexity, depending upon one's personal viewpoint. For convenience and consistency, we will most likely blend elements of the two terms, but use "instructional technology" as our primary focus in this article. Instructional technology may be best understood by reviewing several definitions culled from the writings of several scholars in the field: [Instructional technology] is concerned with improving the effectiveness and efficiency of learning in educational contexts, regardless of the nature or substance of that learning... Solutions to instructional problems might entail social as well as machine technologies (Cassidy, 1982).

The systemic and systematic application of strategies and techniques derived from behavioral and physical sciences concepts and other knowledge to the solution of instructional problems (Gentry, 1995)... the media born of the communications revolution which can be used for instructional purposes alongside the teacher, textbook, and blackboard... [as well as]... a systematic way of designing, carrying out, and evaluating the total process of learning and teaching in terms of specific objectives, based on research in human learning and communications, and employing a combination of human and non-human resources to bring about more effective instructions. (Commis- sion on Instructional Technology, 1970: p. 19) ... the application of our scientific knowledge about human learning to the practical tasks of teaching and learning. (Heinich et al., 2002).

As a field, instructional design and technology has generated an ample number of theories and models (Reigeluth, 1999). But instructional theorists seldom describe the assumptions and beliefs that led them to create their theory or model. Slife \& Williams (1995) discuss the dangers of applying models and modes of practice without first examining the assumptions that underlie these models and practices: [Instructional designers] seem to be building content models and testing them empirically. Unfortunately, however, model testing does not question the assumptions on which the model was built. Models rarely expand our most basic understandings of the phenomena being modeled. Because a discipline is basically a set of ideas-and the quality of those ideas determines the ultimate value of the discipline-scholars in instructional design need to examine the assumptions upon which their models and theories rest. And as future instructional designers are prepared, we need to make these assumptions explicit-tying them, as Shulman (1990) suggests - to specific practices in the profession. To engage in this type of dialectic, we offer a framework based on Stephen Pepper's (1957) book, World Hypotheses, in which he describes four categories for analyzing assumptions associated with any theory. Table 1 shows these four categories with the following column' headers:

1) Formism; 2) Mechanism; 3) Organicism; and 4) Contextualism. The rows of Table 1 include the three primary types of practice and inquiry in the field of instructional design: 1) instructional development; 2) program evaluation; and 3) educational research.

\section{Classroom Technology}

Let us begin with a comprehensive look at school technology in a series of articles by Education Week (1997), which shared several interesting facts about the state of computer technology in public education:

- "The dividends that educators can expect from this... unprecedented support for school technology... are not yet clear... There is no guarantee that technology improves student achievement.” (Trotter, 1997: p. 6).

- $43 \%$ of respondents in a survey felt that the introduction of computers into public schools was not happening fast enough (Trotter, 1997: p. 7).

- Despite the lack of research evidence, $74 \%$ of the public and $93 \%$ of educators agreed that computers had indeed improved the quality of education, teaching, and learning (Trotter, 1997: p. 8).

- Research on the effects of technology on student achievement offers mixed results (Viadero, 1997: p. 12).

Table 1.

A Framework for examining philosophical assumptions and implications.

\begin{tabular}{|c|c|c|c|c|}
\hline & Formism & Mechanism & Organism & Contexualism \\
\hline Instructional Development & Learning outcomes taxonomies & $\begin{array}{c}\text { Outcome-based, objectivist } \\
\text { learning }\end{array}$ & $\begin{array}{l}\text { Systems approach. } \\
\text { Systematic reform }\end{array}$ & $\begin{array}{l}\text { Constructivist-learning } \\
\text { environment }\end{array}$ \\
\hline Program Evaluation & Intelligence \& Aptitude testing & $\begin{array}{l}\text { Realist evaluation, } \\
\text { quantitative emphasis }\end{array}$ & CIPP model & $\begin{array}{c}\text { Stakeholder-based evaluation, } \\
\text { ethnographic methods }\end{array}$ \\
\hline Educational Research & $\begin{array}{l}\text { Construct Development, } \\
\text { Factor analysis }\end{array}$ & $\begin{array}{l}\text { Pure experiments, inferential } \\
\text { statistics }\end{array}$ & $\begin{array}{l}\text { Eclectic research models, } \\
\text { longitudinal studies }\end{array}$ & $\begin{array}{l}\text { Action research, qualitative } \\
\text { studies, narrative research }\end{array}$ \\
\hline
\end{tabular}


- Placing computers and software in classrooms is not enough. Discovering whether technology "works" is not the point. The real issue is when and under what circumstances. Like any other tool, teachers have to come up with a strategy or pedagogy to make it work.

- Wise use of technology takes adequate training, time, planning, support, and teacher ownership (Viadero, 1997: p. 16).

- Money spent on school technology is wasted without an equal effort to help teachers with its use and integration into the curriculum (Zehr, 1997: p. 24). Is it possible that blasphemies are beginning to be heard outside the church of technology? Bronner (1997) posed this question and, in describing an "intellectual backlash" and feelings of skepticism about technology use, cited several educational sources to criticize the use of "glitzy toys" and "bogus stuff" in the middle of an "educational catastrophe" where children cannot read or write. Such a backlash will be productive if it makes us re-examine how we use technology in the classroom (Pool, 1997). Bronner's comment that "schools may be overwired and children undertaught" is cause for reflection for those who feel that "new media tools offer a great promise for a new model of learning - one based on discovery, participation..., learning partnerships, and learning cultures" (p. 4).

The promise is indeed real-as illustrated by recent studies showing that new technologies have indeed transformed classrooms for K-12 students and teachers. "Around the nation teachers are using technology to create exciting and creative learning environments where students teach and learn from each other, solve problems, and collaborate on projects that put learning in a real-world context”. In a metaanalysis of the value and use of technology in K-12 education (Valdez et al., 2000), the North Central Regional Laboratory found that "technology innovations are increasing the demand for reforms in teaching and learning approaches that, in turn, are having a significant impact on technology use expectations" (p. 3). The report also found a very strong connection between appropriate teacher use of technology and increased student achievement. Technology offers opportunities for learner-control, increased motivation, connections to the real world, and data-driven assessments tied to content standards that, when implemented systematically, enhance student achievement as measured in a variety of ways, including but not limited to standardized achievement tests (p. 3).

\section{Model of Communication}

In communication sciences, the word "communication" covers associated concepts such as transfer and dissemination of diverse knowledge and ideas, creating social cohesion and intellectual sharing and cooperation in general. The model consists of the activities that an environment variable permanently, and the relationships have been established when the message sender to the receiver of a message is transmitted. We can then communicate to the transition process from the message sender to the recipient that the mental condition of the message sender is transmitted to the intended recipient, or vice versa. In a communication position, any educational position is the message sender, sometimes designer, sometimes teacher training; moreover, the student is receiving the message. When we say communication has been established that mental design or teacher training or student is the recipient of the message is transferred to the desired mental, student or teacher. Student's performances are measured to realize that it is connected or not. If we want to position components in a communication in the classroom to the analysis of this model so we can (according to Figure 1):

- Source of information: resources professionals that textbooks will be prepared based on their books that are specialized.

- Message: the subjects that are written or an image on the pages of textbooks is closed as the sender: Bachelor Office of Research and Curriculum Development.

- Coder: the sender of the message is encrypted using the resource books in the form of words, designs and makes files.

- Carrier: Carrier messaging, textbook, teacher, black board, etc.

- Receiver: student.

- Encoder: The received message is understood based on the message book and mind.

- Message: writings and images printed on a book.

- Target: students or messaging recipients.

Working in an appropriately designed technology-rich environment has the potential of producing a variety of positive outcomes (Tiene \& Luft, 2001): improved patterns of social interaction, changes in teaching styles, more effective teaching, increased student (and perhaps, teacher) motivation, and enhanced student learning. Achieving this potential, however, is quite challenging, and it requires the correct vision of technology and its integration.

\section{Technology Integration}

\section{Teachers and Technology}

Since the ultimate goal of educational technology instruction is to influence preservice teachers' ability and willingness to use technology effectively in their teaching careers, it is worthwhile to first consider factors associated with teachers' instructional use of computers. Evidence suggests that teachers' intrinsic beliefs about teaching and learning interact with extrinsic factors such as access to computers, software, time, training, and support to facilitate or limit their technology use (Becker, 2000). While teacher educators cannot directly influence external factors that may impact their students' future technology use, they can attempt to influence intrinsic factors such as preservice teachers' abilities and beliefs regarding technology integration.

\section{Abilities}

Basic computer competency has been viewed as a necessary "stepping stone" toward technology integration (Albion, 1999). Technological competence was among the variables that predicted

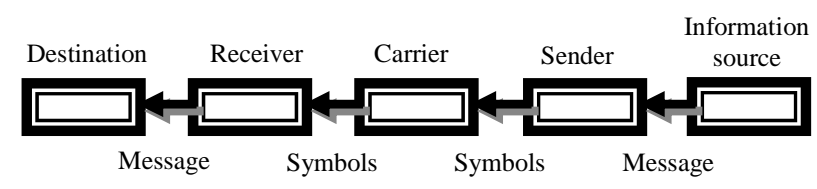

Figure 1.

The model of communication. 
preservice teachers' commitment to use computers, student teachers' computer use, and classroom teachers' computer use. Several researchers have used pre- and post-course surveys to investigate changes in education students' perceptions of their abilities to perform specific computer tasks or to integrate technology in classrooms. Improvements in students' technology skills and knowledge were reported during one-semester educational technology courses as well as in methods courses in which instructors integrated technology (Halpin, 1999). Not surprisingly, Anderson and Boarthwick (2002) found that students enrolled in a stand-alone technology course improved in ability more than students taking a methods course in which technology was integrated. However, Halpin (1999) reported that students who learned to use spreadsheet software in an integrated, rather than isolated, manner were more likely to use it in their first year of teaching.

\section{Beliefs}

Several authors have highlighted the important role of beliefs in determining how teachers use technology in their classrooms.

\section{Self-Efficacy Beliefs}

Evidence suggests a strong relationship between self-efficacy and computer usage patterns (Olivier \& Shapiro, 1993). Bandura (1986) defined perceived self-efficacy as a person's judgment of his or her capabilities to organize and execute courses of action required to attain certain performances. High levels of technology use during student teaching occurred when preservice teachers' confidence in using specific technologies was high and their cooperating teachers also used those technologies. Several studies demonstrated improved self-efficacy or confidence in using computers during educational technology courses (Albion, 2001) and technology-integrated methods courses. In one study, demonstrations of specific computer integration techniques strengthened students' confidence in using technology in their future classrooms. More than $90 \%$ of those students anticipated that they would use spreadsheets and databases in their future classrooms. Researchers have found relationships between technology-related self-efficacy and past success with computers, technology proficiency, perceived value of computers, and use of technology in an integrated project-based learning environment (Kellenberger, 1996).

\section{Value Beliefs}

Teachers are motivated to use technology when they have a clear understanding of how it will improve their teaching and students' learning. Value beliefs involve perceptions of the importance or relevancy of a task for the accomplishment of future goals (Keller, 1983). Swain (2006) found that preservice teachers' perception of the utility of computers was positive, but only improved slightly from the beginning to end of an introductory educational technology course. Preservice teachers' ratings of the value of computer use were associated with their perceptions of the likelihood that they would use computers in their future classrooms (Kellenberger, 1997). Technology-related value beliefs were also correlated with preservice teachers' use of technology in an integrated project-based learning environment. Perceived relevance of computers to teaching and technological self-competence were correlated with each other and together predicted preservice teachers' expectations regarding future computer use. Nearly all (97\%) of the students expected to use computers in their teaching. However when surveyed again at the end of their first year of teaching, only 61\% reported using computers in their classrooms. Their ratings of perceived relevance and self-competence remained high but did not predict actual computer use during the first year of teaching.

The problem of improving performance of students with diverse needs and abilities has concerned teachers throughout the history of modern education. More than fifty years ago the behavioral psychologist B. F. Skinner designed his first "teaching machine” after observing these challenges in his daughter's math class (Skinner, n.d.). Today's classrooms have similar challenges and are more demanding as teachers are expected to reach all subgroups of learners-by ethnicity, socio-economic status, pupil services, and English language proficiency. With limited contact time (Bransford et al., 2000), teachers and schools alone seem to be held accountable for helping all students meet established educational standards and perform well on high-stakes assessments.

American classrooms have not fully succeeded in this effort. Results from the 2003 Program for International Student Assessment (PISA) tests showed that 15-year-old students from 27 countries outperformed the United States in mathematics literacy and students from 28 countries outperformed the United States in problem solving (NL, 2005). These results have reopened the debate about what and how students are taught in secondary schools in the United States (Balasubramanian, 2004). Michael Cole and Yrjo Engeström pioneered the basic analysis of an activity in activity theory. Their ideas are widely used for understanding human-computer interactions, workgroup processes, and learning communities. Figure 2 represents an activity analysis applied to developing "higher literacy skills” (see Abilities) in K-12 students (Bellamy, 1996).

\section{Principles of Integration}

Instructional technology does, indeed, hold a remarkable promise for changing the quality of teaching and learning in our schools. It is the catalyst for transformation-but this does not mean that we merely need more computers in our classrooms. Technology also involves process. Too often efforts to improve education have resulted in unrealistic isolation of technological processes. Remember my earlier reference to our experiences with educational television? We expanded our resources on installing equipment, which soon began to gather dust because we neglected the process components-learning, teaching practices, and curricula. Technologies are valuable resources, but only when used in a systematic process for developing human competence. Questions about technology integration often center around schools and classrooms. Such questions fall short of the target. It is relatively easy to "place" technology in physical locations. The real question must focus on integration into teaching practices, learning experiences, and the curriculum. Integration (from the Latin integrate, to make whole) includes a sense of completeness or wholeness and incorporates the need to overcome artificial separations by bringing together all essential elements in the teaching and learning process-includeing technology (as one of the elements, not the sole element).

According to Meisalo (2006): 


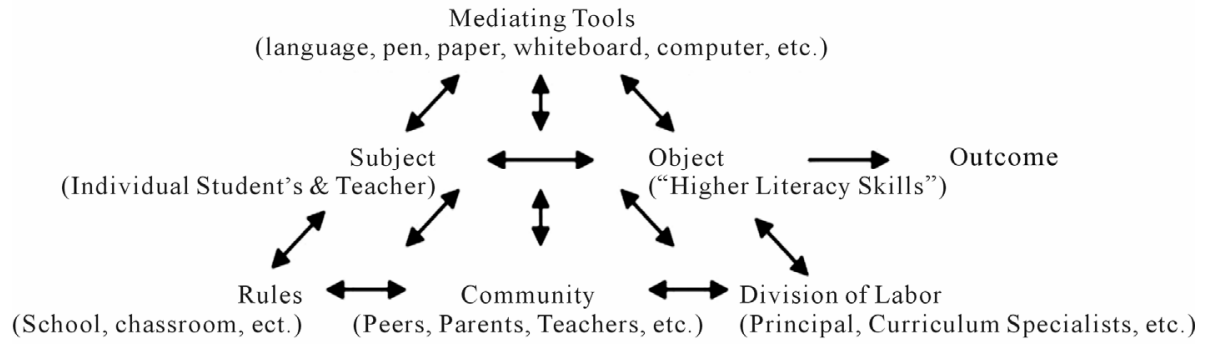

Figure 2.

Cole and Engeström's activity theory framework (Bellamy, 1996).

Beginning in the late $1980 \mathrm{~s}$, the use of ICT in education greatly expanded, spurred by the launch of the microcomputer and following the lead of top American universities and schools, as well as interesting projects in United Kingdom, France and other European countries. Finland, along with many other developed countries, followed a similar path, though sometimes with delays and sometimes finding new paths or development. Finnish experts involved in developing ICT use in education considered teacher education as a key area for the intended breakthrough of new technologies.

In spite of its acknowledged importance, computing did not gain the status of compulsory school subject in Finland. Instead, computing was integrated in all school subjects. Local schools got power to decide how to prepare a curriculum that ensures proper skills in computing for their pupils. That has led to a situation of irregular integration of Information and Communication Technology (ICT) at schools and inconsistent outcomes in student learning. The Finnish National Board of Education (FNBE), which works under the auspices of the Ministry of Education and is in charge of development of education in Finland, has provided massive refresher courses for in-service teachers, and this process continues. A recent Annual Report (FNBE, 2005) delineates grants of EUR 2.5 million for establishing computer networks and purchasing computers for 289 general education providers. This investment led to purchases made by 1082 comprehensive schools, 179 upper secondary schools and 15 other educational institutions. The idea is to ensure an adequate level in infrastructure and know-how among all educators and education providers.

While investing in educational technology, policymakers are certainly looking forward to some payback for that investment. Prior research has documented that technology can support the learning of an individual student by structuring inquiry activities, providing tools for recordkeeping, highlighting essential phases of the process, and guiding metacognitive and reflective activity (Pea, 1993). There is also evidence indicating that technological tools can also enhance students' conceptual understanding by providing tools for organizing, representing, and visualizing knowledge. These higher-level knowledge-construction processes are, nevertheless, invoked only if people, staff and students have skills and willingness to engage in utilizing the potential of ICT in education.

According to Williams, Coles, Richardson, Wilson \& Tyson (2000), teachers' ICT development needs can be categorized into the three major areas:

1) Access to ICT.

2) Appropriate training (in terms of skills, knowledge, relevance to educational goals and priorities; and delivery).

3) Ongoing support to encourage progression beyond initial teacher education or training.

One of the critical issues in teacher education is how to best prepare preservice teachers to integrate technology into their future classrooms. According to one study, novice teachers, many of whom had grown up using technology, were no more likely to use technology than were their peers who had been teaching for over 20 years (Fatemi, 1999).

One possible explanation for this finding is that the teacher education programs did not adequately prepare the novice teachers to use technology in their teaching. Teacher educators must ensure that their students have sufficient technology skills, understand the advantages of using technology in the classroom, and can use it to improve the instruction provided to K-12 students. Many researchers have argued that integrating technology into the teacher preparation curriculum is very important (Collier, Weinburgh, \& Rivera, 2004). However, schools of education in the United States often require students to take a stand-alone educational technology course. This type of course is considered most valuable for building skills that support technology integration during subsequent semesters. Topper (2004) raised several relevant questions related to efforts to prepare preservice teachers to integrate technology in their classrooms:

- How can we tell if our programs are adequately preparing teachers for technology integration?

- What is the relationship between knowledge, skill, and attitudes toward technology?

- How do these concepts relate to technology use or integration in classroom settings?

\section{Reflections}

In (Pelgrum, 2001), in addition to a review of main ICT-indicators for primary and lower secondary education, the main focus is on practitioners' views of what are the main obstacles to the realization of ICT-related goals in schools. The results are from a worldwide survey among national representative samples of schools from 26 countries. The article contains a short summary of the design of this project, a review of main indicators regarding ICT (Information and Communication Technologies) in elementary and lower secondary schools, main obstacles and an exploration of the co-variation between obstacles and contextual factors at the country-level.

\section{Conclusion}

In this paper, a review was performed about instructional technology integration in educational literature. Transitional periods of educational technology were discussed and princi- 
ples of integration of instructional technology in educational technology were reviewed.

\section{REFERENCES}

Pelgrum, W. J. (2001). Obstacles to the integration of ICT in education: Results from a worldwide educational assessment. Computers \& Education, 37, 163-178. doi:10.1016/S0360-1315(01)00045-8

Commission on Instructional Technology (1970). To improve learning: A report to the president and congress of the United States. Washington, DC: US Government Printing Office.

Galbraith, J. K. (1967). The new industrial state. Boston: Houghton Mifflin.

Petroski, H. (1992). The evolution of useful things. New York: Alfred A Knopf.

Seels, B. B., \& Richey, R. C. (1994). Instructional technology: The definition and domains of the field. Washington DC: Association for Educational Communications and Technology.

Anglin, G. (1995). Instructional technology: Past, present, and future (2nd ed.). Englewood, CO: Libraries Unlimited.

Heinich, R., Michael M., James D. R., \& Sharon S. (2002). Instructional media and technologies for learning (7th ed.). Columbus, $\mathrm{OH}$ : Prentice-Hall.

Reigeluth, C. M. (1999). What is instructional-design theory and how is it changing? In C. M. Reigeluth (Ed.), Instructional-design theories and models: A new paradigm of instructional theory (Vol. 2, pp. 5-29). Mahwah, NJ: Lawrence Erlbaum Associates.

Slife, B. D., \& Williams, R. N. (1995). What's behind the research? Discovering hidden assumptions in the behavioral sciences. Thousand Oaks, CA: Sage Publications.

Shulman, L. (1990). Reconnecting foundations to the substance of teaching, TC Record.

Trotter, A. (1997). Taking technology's measure. In Technology counts: Schools and reform in the information age. Education Week, 17, 6-11.

Viadero, D. (1997). A tool for learning. In technology counts: Schools and reform in the information age. Education Week, 17, 12-18.

Zehr, M. A. (1997). Teaching the teachers. In Technology Counts: Schools and reform in the information age. Education Week, 17, 24-29.

Bronner, E. (10 November 1997). High-tech teaching is losing its gloss. New York Times, 4.

Pool, C. R. (1997). A new digital literacy: A conversation with Paul Gilster. Educational Leadership, 55, 6-11.

Valdez, G., McNabb, M., Foertsch, M., Anderson, M., Hawkes, M., \& Raack, L. (2000). Computer-based technology and learning: Evolving uses and expectations. Oak Brook, IL: North Central Regional Laboratory.

Tiene, D., \& Luft, P. (2001). Teaching in a technology-rich classroom. Educational Technology, 41, 23-31.

Becker, H. J. (2000). How exemplary computer-using teachers differ from other teachers: Implications for realizing the potential of computers in schools. Contemporary Issues in Technology and Teacher Education. Journal of Research on Computing in Education, 26, 291-321.

Albion, P. R. (1999). Self-efficacy beliefs as an indicator of teachers' preparedness for teaching with technology. In J. Price et al. (Eds.), Proceedings of Society for Information Technology and Teacher Education International Conference 1999 (pp. 1602-1608). Chesapeake, VA: AACE.

Willis, A. (Eds.) (1994). Technology and teacher education annual
1994. Charlottesville, VA: Association for Advancement of Computing in Education. 742-744.

Cassidy, M. F (1982). Toward integration: Education, instructional technology, and semiotics. Educational Communications and Technology Journal, 20, 75-89.

Halpin, R. (1999). A model of constructivist learning in practice: Computer literacy integrated into elementary mathematics and science teacher education. Journal of Research on Computing in Education, 32, 128-138.

Olivier, T. A., \& Shapiro, F. (1993). Self-efficacy and computers. Journal of Computer-Based Instruction, 20, 81-85.

Bandura, A. (1986). Social foundations of thought and action: A social cognitive theory. Englewood Cliffs, NJ: Prentice Hall.

Kellenberger, D. W. (1996). Preservice teachers' perceived computer self-efficacy based on achievement and value beliefs within a motivational framework. Journal of Research on Computing in Education, 29, 124-140.

Keller, J. M. (1983). Motivational design of instruction. In C. M. Reigeluth (Ed.), Instructionaldesign theories and models: An overview of their current status (pp. 383-434). Hillsdale, NJ: Lawrence Erlbaum.

Swain, C. (2006). Preservice teachers' self-assessment using technology: Determining what is worthwhile and looking for changes in daily teaching and learning practices. Journal of Technology and Teacher Education, 14, 29-59.

Bransford, J. D., Brown, A. L., Cocking, R. R., Donovan, M. S., Bransford, J. D., \& Pellegrino, J. W. (2000). How people learn: Brain, mind, experience, and school (Expanded Ed.). Washington, DC: National Academy Press.

Balasubramanian, N., Wilson, B. G., \& Cios, K. J. (2005). Innovative methods of teaching and learning science and engineering in middle schools. In F. Malpica, F. Welsch, A. Tremante, \& J. Lawler (Eds.), The 3rd International Conference on Education and Information Systems: Technologies and Applications: Proceedings (Vol. 1, pp. 174-178), Orlando, 14-17 July 2005.

Bellamy, R. K. E. (1996). Designing educational technology: Computer-mediated change. In B. A. Nardi (Ed.), Context and consciousness: Activity theory and human-computer interaction. Cambridge, MA: The MIT Press.

Meisalo, V., Lavonen, J., Lattu, M., Juuti, K., \& Lampiselkä, J. (2006). Implementation of ICT strategies in teacher education and the skills of mathematics and science student teachers. In C. Crawford et al. (Eds.), Proceedings of Society for Information Technology and Teacher Education International Conference 2006 (pp. 4026-4033). Chesapeake, VA: AACE.

Pea, R. D. (1993). Practices of distributed intelligence and designs for education. In G. Salomon (Ed.), Distributed cognitions. Psychological and educational considerations (pp. 47-87). Cambridge: Cambridge University Press.

Williams, D., Coles, L., Richardson, A., Wilson, K., \& Tuson, J. (2000). Integrating information and communications technology in professional practice: An analysis of teachers' needs based on a survey of primary and secondary teacher in Scottish schools. Journal of Information Technology for Teacher Education, 9, 167-182. doi:10.1080/14759390000200089

Fatemi, E. (1999). Building the digital curriculum: Summary. Education Week, 19, 5-11.

Collier, S., Weinburgh, M., \& Rivera, M. (2004). Infusing technology skills into a teacher education program: Changes in students' knowledge about and use of technology. Journal of Technology and Teacher Education, 12, 447-468. 